\title{
Use of Financial Ratios in selecting entities for Tax Audit purposes - empirical study in Albania.
}

\author{
REZARTA SHKURTI (PERRI) \\ Professor, University of Tirana, Albania \\ Orcid ID: 0000-0002-2126-2339 \\ ELENA MYFTARAJ (TOMORI) \\ Professor, University of Tirana, Albania \\ ELSIA GJIKA \\ Tax Directorate, Albania
}

\begin{abstract}
Information from financial statements and reported financial ratios have long been used to detect common phenomenon such as fraudulent financial statements, earnings management, and the relation between financial ratios and the level of tax risk of an entity. The focus of this study is to research the use of financial ratios that entities declare, in the detection of the magnitude of tax avoidance. In this paper we apply a binary logistic regression to detect which financial statement ratios differentiate between tax evading and non-tax evading entities. We analyse data from 183 tax audited Albanian entities for 2015 and 2016 accounting years and calculate several financial ratios to determine the level of tax risk based on the tax evasion magnitude found by the tax audit of these entities. We apply univariate and multivariate analysis and find several important ratios that can indicate quite accurately the high risk of tax audit of an economic entity. We suggest including these ratios as risk indicators or "red flags" in the selection procedures employed by the tax auditors. As tax reporting and financial reporting have similarities across countries of the region, our findings may be useful for other Southern Eastern European Countries as well.
\end{abstract}

Keywords: tax audit, tax risk, financial ratios

Received: October 10, 2020. Revised: March 8, 2021. Accepted: April 6, 2021. Published: April 14, 2021.

\section{Introduction}

The accurate assessment of the tax risk levels of economic entities is an important focus of the tasks of any Tax Administration. It is extremely important for the tax authorities to be able to manage the scarce tax audit resources with effectiveness and efficiency, hence the special focus on determining the tax risk which in turn would orient the scarce tax audit resources towards the entities with a high tax risk. The tax risk from the perspective of the Tax Authorities is the risk that companies may calculate, report, or pay incorrect amount of taxes (including both income and indirect taxes). To mitigate the overall level of the tax risk, the Tax Administration employees, (the tax auditors), engages in tax audits, whose primary focus is the examination of an organization's or individual's tax return to verify that financial information is being correctly reported. Usually, tax audits represent a considerable time demand for tax auditors as they imply on-site controls and inspections for the audited companies what is a major hassle for them. Therefore, carefully selecting the tax audit subjects represents a major purpose in effectively managing Tax Administration resources and minimizing the probable false 
identification of either tax evading or non-tax evading entities.

There have been attempts to link the tax risk level of an entity with risk indicators (red flags) extracted from its financial statements and filed and reported information. Therefore, this study aims to contributing towards a stream of research that uses financial ratios and reported financial information to detect high tax risk entities.

Usually, the selection procedures of the companies that will be subjected to a tax audit go in two stages. In the first step the Risk Module of the Information System of the Tax Administration, based on indicators and red flags derived by its internal Business Intelligence algorithms, selects up to a certain percentage of entities that will be audited. The remaining entities are manually selected by the tax auditors based on a close follow up of the activities of the entities (in Albania this represents a $70 \%^{1}$ to $30 \%$ ratio between both categories). In this paper we specifically focus on the second step, the selection procedures that tax auditors usually follow to select what they think should be the entities that should be audited. To have a more objective framework to select the audited companies, we propose to make use of indicators or red flags from the financial statements, hence the tax auditors will not be perceived as being subjective in their choices. According to the data published from the Tax Administration in Albania for 2017 the amount of tax evasion discovered from entities manually selected from tax auditors is higher (23.274 Euro on average) than the amount of tax evasion discovered in entities selected by the Risk Module of the Information System (20.558 euro on average). This again supports the idea of how important it is having clear and unbiased

\footnotetext{
${ }^{1}$ The ratio $70 \%$ to $30 \%$ in favor of selection from the Risk Module is a policy imposed from higher levels in decisionmaking ranks of the Tax Administration and Ministry of
}

procedures of manually selecting the tax audited companies.

To manually select the entities which will be subjected to a tax audit, the tax auditors usually rely on continually monitoring the performance and activity of the companies such as the amount of the reported revenues, the amount of declared and paid Value Added Tax and other taxes payable. During this process they are also oriented and guided by some Risk Indicators which are traditional financial ratios easily calculable from reported financial statements - current ratio, acid test ratio, total debt ratio, debt to equity ratio, times interest earned ratio, return on assets, return on equity and operating profit margin.

On a closer review of the Risk Indicators, we observe two aspects which, given the high reliance that the tax auditors have on these indicators, can be considered faulty: first, the Risk Indicators do not represent a complete and comprehensive coverage of financial ratios from different perspectives of performance analysis; there are liquidity ratios, debt ratios and profitability ratios, but no turnover ratios and neither cash flow indicators. As a second observation, we find that the thresholds for some of the ratios are far from the widely accepted optimal values for these ratios (for instance, we see an optimal value of current ratio to be 0.42 times, which is quite far from the optimal value of 1.50 times, widely accepted for this ratio). What we aim through this research is to "update" the list of financial ratios which could serve as red flags or risk indicators for the tax auditors, but not only. The findings of this study also aim to fill the gap that exists in the literature of financial ratios use in earnings management, fraudulent financial reporting and tax audit in

Finances of Albania and whether that rule is yielding the best results on the performance of the Albanian Tax Administration or not, it is a matter that goes beyond the scope of this study. 
Albania and the South Eastern European Region. Some relevant studies can be found in [1] and [2], but nevertheless we observe there is more to study in this regard.

The rest of this paper is organized as follows. In the following section we focus on the literature review by adopting a relatively broad view. While studies focusing in finding linkages between audit risk (and especially tax audit risk) and financial ratios are very scarce, research in the broader context of earnings management and fraudulent financial reporting are more common and offer rich insights as to the probable indicators and variables that we could use. Next, in the third section we present the methodology by giving an overview of the sample selection procedures, variables included, and the techniques used to analyze the data. In the data analysis section, we present the two analysis tools we have employed, the univariate and the multivariate technique and the logistic regression models. In the last section, we summarize the main findings of the study and come up with conclusions as to which are the most informative ratios regarding the tax risk level. Advantages of this study are the use of confidential information from Tax Authorities Database and Information System (accessed via a Non-Disclosure Agreement with this Institution) the use of real cases and findings from recent tax auditing processes. Having said that, as an empirical research, this study is limited to reflect the characteristics of Albanian companies and is also limited to the time frame constraints of the data set used to generate the model.

\section{Literature Review}

We find the literature to be complete in articles, papers and studies that focus on the fraudulent financial reporting and earnings management. These studies usually describe techniques to detect manipulation and incentives to engage in earnings management in both dimensions, inflating earnings to achieve the maximization of shareholders value and on the other hand deflating earnings to minimize the taxable income $[3$; $4 ; 5 ; 6 ; 7 ; 8 ; 9 ; 10]$. We find less studies, though having a specific focus on the connection between financial ratios and tax risk. Therefore, we adopt a broad approach in the literature review section by considering all studies about fraudulent financial reporting and earnings management. Our special focus is on papers that reveal how we can use the information in the reported financial statements to detect manipulated financial statements.

For having a complete overview on previous results on this field we searched through work from various authors, $[11 ; 12$; $13 ; 14 ; 15 ; 16 ; 17 ; 18 ; 19]$ whose research is based on using financial ratios for detecting manipulative financial statement. Their findings suggest that some financial statement figures are informative and that the use of several financial ratios could be useful in detecting companies that might have been involved in fraudulent activities and general manipulation of financial statements.

One study based on Finnish firms [20], which are mostly known to manage earnings downward (a similar situation as that of Albania) suggested that fraudulent companies in addition to managing earnings downwards on a grander scale, simultaneously manage earnings upwards in a smaller scale. They show that firms tend to adjust the earnings and the tax audit risk, to avoid "being caught" thus requiring a greater attention from tax authorities to select more carefully the entities that will be subject to tax audits in the future.

We see that the earnings management and fraudulent reporting research usually employs either the discriminant analysis or logistic/probit models. To achieve more reliable results from empirical studies, and to 
expand the scope of the research, authors have combined the use of big data sets with advanced and innovative techniques. In one study in 2002 [21], it was attempted to identify the factors associated to Fraudulent Financial Statements using the multi-criteria decision aid (MCDA) technique. Their results reveal that the proposed MCDA methodology outperforms traditional statistical techniques which are based in only one criterion. They also highlight the importance of using the familiar financial ratios such as the total debt ratio, the inventories to sales ratio, the net profit margin and the sales to total assets ratio as indicators to detect fraudulent financial statements. One year later, in 2003, in USA another study [22] indicated that the use of certain financial data from financial statements could be successfully used to correctly assess the taxpayers by the tax auditors.

In another study [23] the use of computer-assisted audit techniques (CAATs) to investigate for fraud and accounting irregularities detection based on big data, was employed. The study proposes an expert system for identifying suspicious irregularities in detailed financial data and techniques for automatic analysis of company ledgers on a large scale, identifying irregularities. They even name their system Sherlock and demonstrate that if possessing huge data sets with detailed financial information it is possible to use advanced technological tools to build an expert system that assists auditors in detecting irregularities and fraud. This idea could be useful not only for Tax Administrations but also for the big audit firms that have already collected enough data to train the expert systems.

In one study of 2011, [24] the use of sophisticated audit tests was analyzed by arriving at the conclusion that the combination of sophisticated audit tests with a graphical presentation of possible inconsistencies, could lead to obtaining a higher chance of preventing problems with internal controls or detecting them when they occur. The same study emphasized the importance of implementing continuous auditing embedded modules in the Information System to help auditors have higher assurance level of transaction integrity and reliability. Other authors also propose the use of big data sets combined with the data mining techniques to increase the effectiveness of selection of audited [25]. The techniques proposed by them were reported to be successful and could help the tax administration to better manage the process of selecting the entities that will be audited and minimizing error I and error II of false categorization of entities in risk of fraud.

Advanced tools in detecting the entities with the probable higher tax audit risk, such as the neural networks were also used in a study in 2011 in Finland [26]. The authors investigate how well an unsupervised neural network method - the Self-Organizing Map (SOM) - can perform in detecting those companies that need to be tax audited. The findings of the study report an outperformance of SOM neural networks to ordinary approaches commonly used by the tax inspectors, hence introducing a possibility of using such a technique to improve the overall performance of the tax auditing processes.

As another common theme in literature review on detecting fraudulent financial statements for tax purposes we encounter the use of the Benford's Law as a rule that describes the distribution of first (leading) digits in economic or accounting data, but also in every kind of data. Two studies in 2008 and 2018, [27 and 28] have studied whether Benford's Law can be used to improve selection of the entities prior to tax audits, thus increasing effectiveness and efficiency of this process. The findings from both studies report that manipulated financial 
statements data deviate significantly from Benford's Law rule of numbers and therefore this law can be used as a tool for audit selection.

Another stream of research in the literature review is the use of financial ratios and other reported information derived from the financial statements as variables linked to the level of tax risk of entities. In a 2001 article, [29] the authors demonstrate by a real-life example the importance of using basic financial analysis techniques like vertical, horizontal, and ratio analyses that can give an auditor hints in identifying probable fraudulent financial statements. Indexes such as sales in receivables index, gross margin index, asset quality index, sales growth index, total accruals to total assets index derived by the original Beneish model were also discovered to be useful. Another study [30] examined the detection of fraudulent financial reporting using both financial ratios and nonfinancial factors related to corporate governance and employing a probit technique. This study found that a combination of quantitative financial ratio indexes and qualitative corporate governance factors such as CEO power, management control systems, senior management turnover insider stock trading, appears to work best for detecting fraudulent financial reporting. Studies, discovering discrepancies between the accounting information and the real situation $[31 ; 32]$, are also useful in emphasizing the importance of reported financial information.

Earnings management studies in Albania have also been very limited. One study in 2011 [33] shows the existence of practices or attempts for earnings management on behalf of Albanian companies. Another Albanian author, [34] in her study of 2013 also searches for empirical

\footnotetext{
${ }^{2}$ The tax audits performed in a certain year cover two previous financial years, and this means that the tax audit engagements conducted in 2017 and reported in 2018,
}

evidence on the phenomenon of earnings management among Albanian companies, using the Jones model. The results confirm that firms in the Albanian market are engaged in earnings management initiatives mainly for tax purposes, therefore demonstrating deflation of revenues and income.

\section{Methodology}

The purpose of this research is to reveal whether the information contained in the financial ratios and indicators could indicate tax level risk for entities, thus helping tax auditors during the selection procedures and. To find if there is any link between financial information and tax risk, we will study the information represented in the financial ratios that can be computed from reported financial statements and the level of tax evasion that is subsequently discovered by tax auditors after they have conducting the tax audit.

\subsection{Sample selection}

This study was performed by the end of 2018 and the first months of 2019. Therefore, the latest data available was from reports on tax audits performed during $2017^{2}$ (data for year 2018 was not yet reported by the time of sample design). The data we have used in this study is derived from tax audit reports for year 2017 for all regional tax directories of Albania. This is confidential information that we could access only because of the current engagement of one of the authors of the paper. The data was made available to us upon a Non-Disclosure Agreement.

In total, 1402 economic entities were audited in Albania in 2017. We decided to select a sample consisting of 15 percent of the total population, which is about 210 entities. The sample was randomly selected using the random selection option of MS Professional Excel, as the list of audited

focus on data from financial statements and tax return of 2015 and 2016 for the audited entities. 
entities was received in an excel file format. As the second step, after having the sample, a list of selected entities, we accessed (again under a confidential privileged access rights clause) the Information System of Tax Administration and downloaded the full financial statements and tax returns for the audited periods (2015 and 2016) for all the companies in the sample. As a third step we carefully observed the data we had and decided to discard from the sample those entities which either were microenterprises (with less than 5 employees), or for which there was not complete financial information in the database of Tax Administration (either one statement or the other was missing). After this step of data selection, we were left with 183 entities at our final sample, for which we have complete financial statements and filed tax returns for year 2015 and 2016 and also the Tax Audit Report which reports for the level of tax evasion, if any found after the tax audit is performed on these entities.

Further, to facilitate the data analysis and to perform different tests, we have sub classified the sample first according to the industry activities and second according to their size. We have grouped the entities by type of activity: construction $\&$ manufacturing, service \& transport, and commerce, and coded them by category with 1,2 and 3 accordingly. A further categorization of entities was performed according to their size (size refers either to total assets figure, total revenues or to the number of employees). The size of the firm will later serve as a controlling variable during data analysis. We also divide the companies in the sample in two different categories based on the level of magnitude of tax evasion which will be the dependent variable in this research. If the tax evasion was from $0-50.000$ Albanian Lek (approximately 400 Euro) we have considered the entity to be risk-free or of minimal-risk and have coded it with 1 ; whereas if the level of the magnitude of tax evasion was found to be higher than 50.001 Albanian Lek (400 Euro), we have coded that entity with 2 .

\subsection{Variables included in the study.}

Previous research on using financial ratios for detecting overall manipulative reporting revealed that the use of several ratios might be informative and useful in detecting companies that more than others might have been involved in fraudulent activities and manipulation of financial statements. From reviewing these studies, $[10 ; 16 ; 17 ; 18 ; 35 ; 36$; $37 ; 38 ; 39 ; 40]$, we found that several common ratios were consistently reported to detect fraud and manipulating activities. For example, likely items to be subject to manipulation are sales, accounts receivables altogether with the allowances, and inventory because of their subjective nature and the judgements involved with determining the reported amount of these items. Usually, the fraudulent companies report inflated or deflated sales by inappropriately applying the revenues recognition standards; they do not match sales with the appropriate cost of goods sold and this is reflected in ratios such as profit margins (on a gross, operating, or net basis); or they tend to report the inventory at a lower cost than cost or market value hence impacting again the cost of goods sold but also the inventory to total assets ratio. Also, higher debt ratios are reported [35] to be associated with fraud due to the probable wealth transfer from debt holders to managers which increases as leverage increases as shown in at least one study [41].

Based on these findings from literature review we pooled a list of ratios that previous studies have found to be relevant in the financial analysis for tax audit purposes. This list is further completed with other ratios, mainly suggested from theoretical literature (academic textbooks) and also based on practical experience and insider 
information of the authors. (With insider information we refer to confidential information from Tax Administration database on the main areas identified as more prone to tax evasion for audited Albanian companies in 2017. For example, revenue deflating by non-reporting revenue was observed in $47 \%$ of all cases - 656 entities; errors in completing tax return file in $32 \%$ of cases -449 entities; other cases $-21 \%$ are related to non-declaration of expenses. Based on these findings we inserted related

\begin{tabular}{|c|c|c|c|c|c|}
\hline No. & 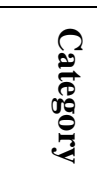 & Financial Ratio & $\begin{array}{l}\text { Optimal } \\
\text { Standard Value }\end{array}$ & $\begin{array}{l}\text { Source of } \\
\text { standardization of } \\
\text { optimal vale }\end{array}$ & Codification \\
\hline 1 & \multirow{3}{*}{ 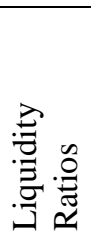 } & Current Ratio & $150 \%$ & $\begin{array}{l}\text { Theoretical } \\
\text { literature }\end{array}$ & $\begin{array}{l}0 \text { if less than } 150 \% \\
1 \text { if more than } 150 \%\end{array}$ \\
\hline 2 & & Acid test (quick) Ratio & $100 \%$ & $\begin{array}{l}\text { Theoretical } \\
\text { literature }\end{array}$ & $\begin{array}{l}0 \text { if less than } 100 \% \\
1 \text { if more than } 100 \%\end{array}$ \\
\hline 3 & & Liquid Ratio & $50 \%$ & $\begin{array}{l}\text { Theoretical } \\
\text { literature }\end{array}$ & $\begin{array}{l}0 \text { if less than } 50 \% \\
1 \text { if more than } 50 \%\end{array}$ \\
\hline 4 & \multirow{3}{*}{ 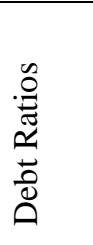 } & $\begin{array}{l}\text { Non-Current Liabilities to Total } \\
\text { Assets Ratio }\end{array}$ & $30 \%$ & $\begin{array}{l}\text { Theoretical } \\
\text { literature }\end{array}$ & $\begin{array}{l}0 \text { if more than } 30 \% \\
1 \text { if less than } 30 \%\end{array}$ \\
\hline 5 & & Total Debt Ratio & $50 \%$ & $\begin{array}{l}\text { Theoretical } \\
\text { literature }\end{array}$ & $\begin{array}{l}0 \text { if more than } 50 \% \\
1 \text { if less than } 50 \%\end{array}$ \\
\hline 6 & & Times interest earned & 5 times to 1 & $\begin{array}{l}\text { Theoretical } \\
\text { literature }\end{array}$ & $\begin{array}{l}0 \text { if less than } 5 \\
1 \text { if more than } 5\end{array}$ \\
\hline 7 & \multirow{4}{*}{ 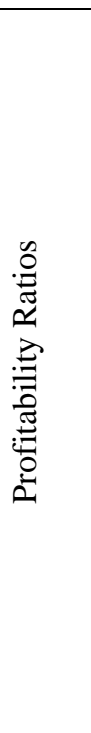 } & Net Profit Margin & $\begin{array}{l}\text { Varies according } \\
\text { to industries }\end{array}$ & $\begin{array}{l}\text { INSTAT data about } \\
\text { average profit } \\
\text { margin according } \\
\text { to each industry }\end{array}$ & $\begin{array}{l}0 \text { if less than average of } \\
\text { industry } \\
1 \text { if more than average } \\
\text { of industry }\end{array}$ \\
\hline 8 & & Profit before Taxes (EBT) Margin & $\begin{array}{l}\text { Varies according } \\
\text { to industries }\end{array}$ & $\begin{array}{l}\text { INSTAT data about } \\
\text { average profit } \\
\text { margin according } \\
\text { to each industry }\end{array}$ & $\begin{array}{l}0 \text { if less than average of } \\
\text { industry } \\
1 \text { if more than average } \\
\text { of industry }\end{array}$ \\
\hline 9 & & Return on Assets ROA & $\begin{array}{l}7 \% \text { adjusted with } \\
\text { inflation }(1.6 \% \text { in } \\
2015 \text { and } 2.6 \% \text { in } \\
2016)\end{array}$ & $\begin{array}{l}\text { Theoretical } \\
\text { literature }\end{array}$ & $\begin{array}{l}0 \text { if less than } 7 \% \text { before } \\
\text { adjustments } \\
1 \text { if more than } 7 \% \text { before } \\
\text { adjustments }\end{array}$ \\
\hline 10 & & Return on Equity ROE & $\begin{array}{l}\text { Interest rate } \\
\text { percentage } \\
(2.25 \% \text { in 2015 } \\
\text { and } 2 \% \text { in 2016) }\end{array}$ & $\begin{array}{l}\text { Theoretical } \\
\text { literature }\end{array}$ & $\begin{array}{l}0 \text { if less than interest rate } \\
1 \text { if more than interest } \\
\text { rate }\end{array}$ \\
\hline
\end{tabular}

Table 1.1. List of financial ratios used as independent variables.

Source: Primary data of the study. Formulas and optimal standard values of these ratios are based either on wide known theoretical literature of financial statement analysis, or on data derived from INSTAT, the Albanian Institute of Statistics indicators in the list of ratios/variables of the study).

The list of 10 financial ratios in table 1.1 will be the first independent variables included in the study (later we will include 8 more variables to the list). We have calculated these ratios for the firms included in the sample and will try to use the dataset to conduct analysis that can reveal which of the ratios contain information on identification of probable tax evading entities. 
As mentioned, we also added eight other various financial ratios, for years 2015 and
2016. These other ratios are shown in table 1.2 .

\begin{tabular}{|l|l|}
\hline No. & Other financial ratios \\
\hline 1 & NCA Ratios = Fixed Assets to Total Assets \\
\hline 2 & Inventory Ratio = Inventory to Total Assets \\
\hline 3 & (Inventory + Accounts Receivable) / Total Assets \\
\hline 4 & Total Personnel Expenses to Total Revenues \\
\hline 5 & Operating Profit Margin \\
\hline 6 & Administrative Expenses to Total Revenues \\
\hline 7 & Difference between taxable income and reported income to total Revenues \\
\hline 8 & Cash Flow from Operating Activities to Net Income \\
\hline
\end{tabular}

Table 1.2: Financial ratios calculated for entities included in the sample for both years but not included in the univariate model due to lack of standardized information from INSTAT. This information is part of the database and is utilized only in the multivariate analysis.

We included these financial ratios in the study, because based on our personal experience, and on findings from tax audits we noticed that these ratios were important and relevant during the audit process. Nevertheless, we could only partially include these ratios as variables in the study due to the lack of optimal or standard values in literature and because we found no comparable data in the webpage of INSTAT, the Albanian Institute of Statistics, like we have for the variables included in table 1 .

The independent variable of the study is the magnitude of tax risk of tax audited entities. As this is an empirical study and is based on real tax audit cases, the noncompliance with the Albanian tax laws is used as the measurement of the fraudulent tax reporting and therefore the tax risk is measured by the amount of the tax evasion discovered to be performed by the entity. If the tax evasion amount for each studied entity in the sample was found to be low (from 0 50.000 Albanian Lek approximately, 400 Euro) we have considered the entity risk-free or minimal-risk and have coded it with 1, whereas if the level of the magnitude of tax evasion was found to be high (more than 50.001 Albanian Lek approximately 400 Euro), we have coded that entity with 2 .

With this set of eighteen independent variables and one dependent variable we will apply both a univariate and a multivariate technique analysis to our sample of 183 audited entities to find if there is any connection between the financial ratios (independent variables) and the level of the tax risk (dependent variable).

\section{Data analysis}

Based on the literature review where we find as the most widely used techniques either discriminant analysis or logistic regression, we have decided to use the latter as the most appropriate given the characteristics of the sample. We have analyzed the data through two different techniques. First, we have performed a univariate analysis focusing on each independent variable one at a time and at a second stage we have performed a multivariate analysis based on a binary logistic regression model.

In the univariate analysis we have compared if there is a statistically significant difference in categorizing entities according to their tax risk and according to the optimal level of each financial ratio. This comparison is performed independently for both years, 2015 and 2016 initially for the whole data set (no categorization according to the size or industry sector) and results are shown in Table 2. (Complete analytical data output can be found in Annex 2). For example, for the current ratio we find no statistically 
significant difference between the two groups of entities categorized based on tax risk (pvalue $>0.05$ or sig $>0.05$ ). This means that based on a univariate analysis the current ratio is not an important ratio to be used in

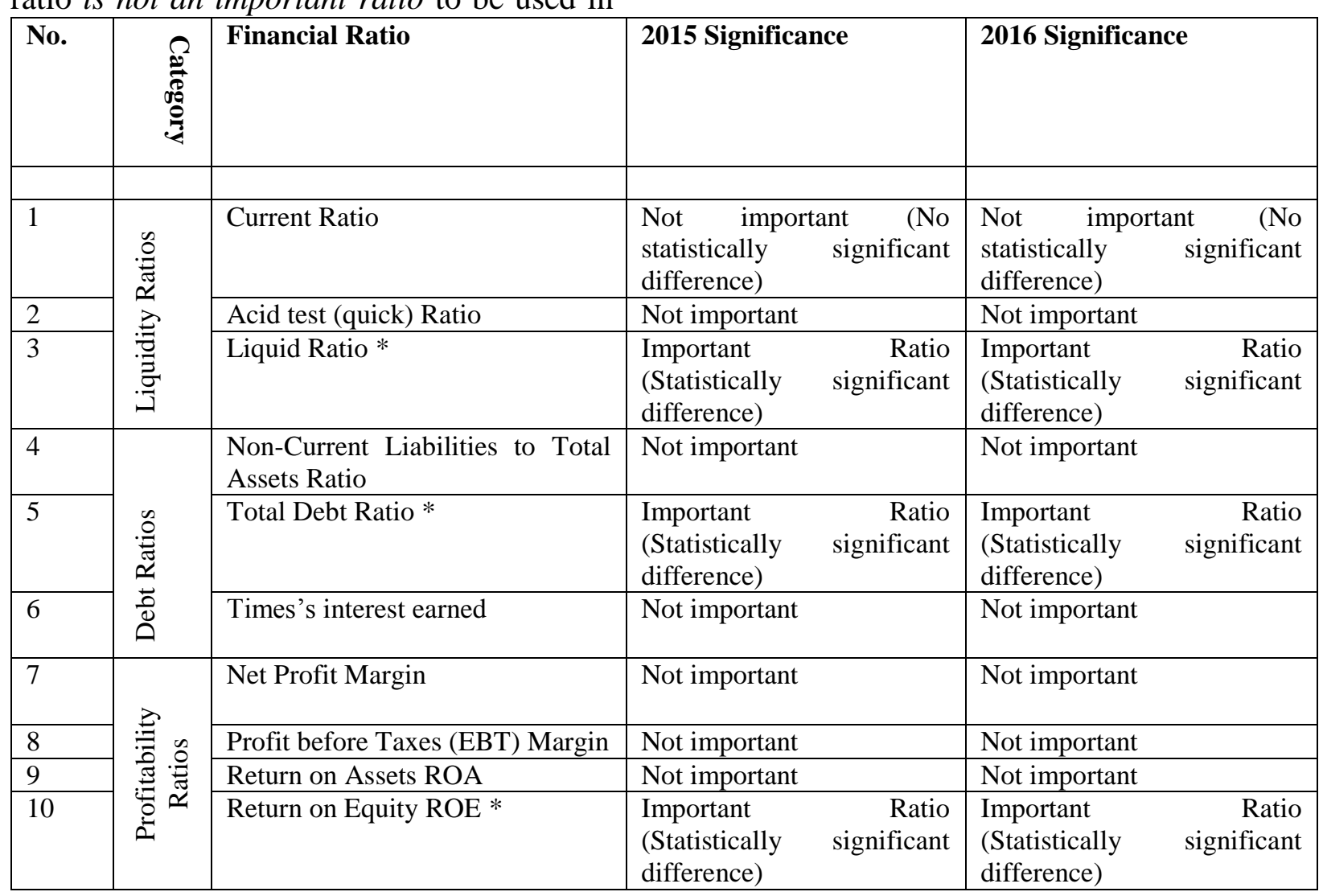

Table 2. Significance of individual financial ratios in categorizing entities as risk free or with a high tax risk. All data set.

Source: Primary data of the study.

Based on what we observe from table 2, based on a univariate analysis for most of the ratios we do not find valuable information contained in their values if they are considered one by one in the analysis of tax risk; that is except for the Liquid Ratio, Total Debt Ratio and ROE that result important in the univariate analysis, the other ratios have demonstrated to have almost the same average values across the group of risk free entities and the group with high risk. As a next step for this technique, we have continued the univariate analysis by performing the statistical significance test for each different industry sector, having in mind the analysis of tax risk of entities because it does not help the tax auditor to discriminate between entities with a high tax risk and those with low or free tax risk. 
in this model the ten financial ratios for which we had a threshold or a criterion that helped us to categorize them in optimal or nonoptimal vales. Again, the dependent variable is the level or magnitude of the tax audit risk. Firms with low tax risk (having tax evasion lower than 400 Euro) are coded with 1 and those with high tax risk (having tax evasion higher than 400 Euro) are coded with 2.
As a first step, to avoid the multiple collinearity problems, we first excluded from the model those variables who had a correlation statistically significant at level of significance $\alpha=0.05$. Next, we also excluded the outliers. Table 3 represents results from Model I, the logistic regression analysis based on the sample with all the entities, run separately for both years.

\begin{tabular}{|c|c|c|c|c|c|c|c|c|}
\hline & \multicolumn{4}{|l|}{2015} & \multicolumn{4}{|l|}{2016} \\
\hline & B & S.E. & Wald & $\operatorname{Exp}(\beta)$ & B & S.E. & Wald & $\operatorname{Exp}(\beta)$ \\
\hline Total Debt Ratio & $-1.314^{* * *}$ & .489 & 7.215 & .269 & .676 & .535 & 1.598 & 1.965 \\
\hline NCA Ratio & 1.340 & .958 & 1.957 & 3.820 & $-2.126 * *$ & .846 & 6.314 & .119 \\
\hline Inventory Ratio & .880 & .744 & 1.401 & 2.412 & $-1.548^{*}$ & .823 & 3.538 & .213 \\
\hline Net profit margin & -1.548 & 1.473 & 1.104 & .213 & -1.530 & 1.283 & 1.422 & .217 \\
\hline Revenue & $.011 * * *$ & .004 & 7.148 & 1.011 & $.000 *$ & .000 & 3.707 & 1.000 \\
\hline Constant & $1.500 * * *$ & .490 & 9.362 & 4.484 & $2.151 * * *$ & .647 & 11.040 & 8.596 \\
\hline $\mathrm{N}$ & \multicolumn{4}{|l|}{175} & \multicolumn{4}{|l|}{183} \\
\hline
\end{tabular}

Table 3: Logistic Regression Analysis, Model I, or Total model for the whole data set 175 \& 183 observations, respectively in each of the two years.

Source: Primary data of the study. $(* \mathrm{p}<0.1 * * \mathrm{p}<0.05 * * *<0.01)$ NCA (Non-Current Assets) ratio is Fixed Assets to Total Assets and Inventory Ratio is equal to Inventory to Total Assets

The regression model for both years, Model I, includes as explaining variables the Total debt ratio, NCA ratio, Inventory ratio, Net profit margin and the Total Revenues which serve as a variable to control for the size of the entities. For 2015, Model I (the total model) is statistically significant $\chi^{2}$ $(\mathrm{DF}=5)=16.334$, $(\mathrm{p}$-value $<0.01)$, Pseudo $\mathrm{R}^{2}$ is 0.152 . This means that the explaining variables make a statistically significant classification between entities with a high risk and entities with a low risk. The percentage of correctly classifying the entities with high risk is $99.3 \%$, whereas the total percentage of correctly classifying all the entities both with high and low risk is 84.6 $\%$.

We can see that in 2015, the Total Debt Ratio (p-value<0.01) and the Revenues (p-value $<0.01)$ are statistically significant what confirms the importance of the total revenue level and the total debt level in determining the entities which have a higher probability to have higher tax risk. The level of the NCA ratio ( $\mathrm{p}$-value>0.1) shows that the percentage of investments in fixed assets is not statistically significant. We can say the same for the inventory ratio and the net profit margin, they do not result to be statistically important in Model I for 2015.

For 2016 the Model I (total model) is also statistically significant $\chi 2 \quad(\mathrm{DF}=5)$ $=19.270$, (p-value<0.01), Pseudo $\mathrm{R}^{2}$ is 0.174, that is for this year the explaining variables can help in classifying between entities with high and those with low tax risk. The percentage of correctly classifying all the entities both with high and low risk is $85.6 \%$. Statistically significant variables for 2016 are the NCA ratio, Inventory ratios and the Revenues (whereas in the previous year the NCA ratio and the Inventory ratio were not statistically significant). The 2016 Revenues are again, as in 2015, an important explaining variable (p-value $<0.1)$. 
What we find unusual in the findings of the regression analysis for the audited entities is the net profit margin ratio, which resulted to be a statistically insignificant ratio. This may be very well explained by the formula used to calculate this ratio. We believe that this ratio, as calculated based on the reported income and not on taxable income is hiding the true "maneuvers" that companies are usually engaged in, to perform tax evasion. From personal experience of the authors, we know the profit margin to be one of the first ratios that a tax auditor checks. This fact is well known to everyone, including businesses who subsequently try to artificially adjust the taxable income and bring it to the "right amount". On the other hand, if the entity has a lower than the industry average net profit, he again adjusts this ratio to bring it within the parameters that he knows are usually accepted. As usual mechanism for this earnings management practice, companies may regard a portion of their expenses as non-tax deductible, thereby increasing taxable income and improving the value of this ratio, so that the tax auditor will not detect them.

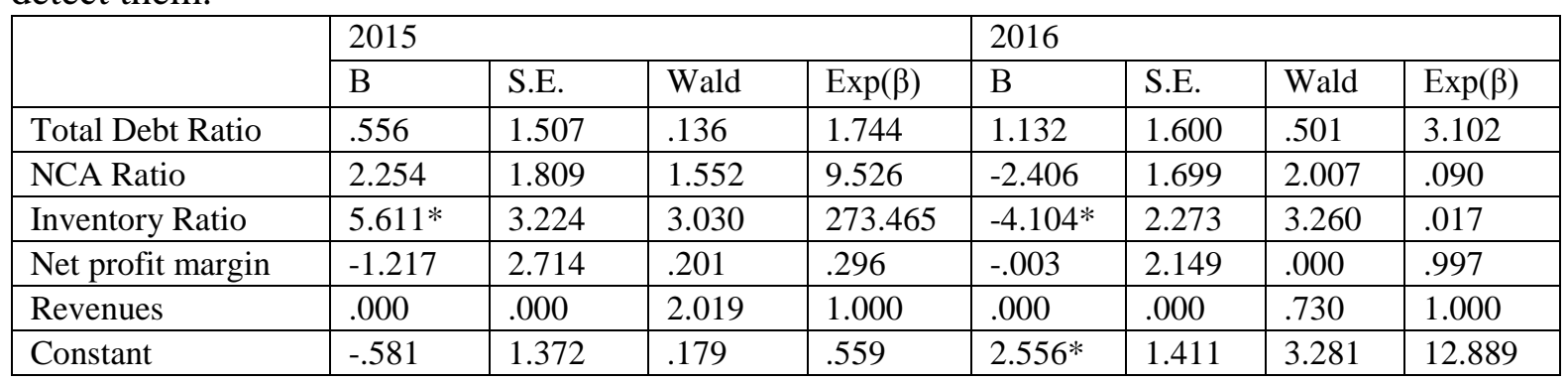

Table 4: Logistic Regression Analysis, Model II, for data for sector 1, Construction \& Manufacturing respectively in each of the two years.

Source: Primary data of the study. $\left({ }^{*} \mathrm{p}<0.1\right)$ NCA ratio is Fixed Assets to Total Assets

Regarding sector 2, Services and Transport, Model III resulted to be statistically not significant for $2015\left(\chi^{2}\right.$ $(\mathrm{DF}=5) \quad=0.793$, (p-value $>0.1)$ and we provide its details only on detailed statistical
The next step in our multivariate analysis is to run logistic regression separately for the entities in the Construction \& Manufacturing sector (Model II), entities in the Service \& Transportation Sector (Model III) and entities in the Merchandising sector (Model IV). After clearing the outliers, in the Construction \& Manufacturing Sector we have 51 entities / observation for each year. For year 2015 the Construction \& Manufacturing sector (Model II, Table 4), was statistically significant $\chi^{2} \quad(\mathrm{DF}=5)$ $=10.066$, $(\mathrm{p}<0.1)$, Pseudo $\mathrm{R}^{2}$ is 0.325. The total percentage of correctly classifying all the entities both with high and low risk is $88.2 \%$. For 2015 the only statistically significant variable is the Inventory Ratio which is statistically important at 0.1 significance level. We see that Revenue variable has the same impact in this model as with the Model I, but in this case, it is not statistically significant. Model II for year 2016 is not statistically significant as seen in table 4.

appendixes of this study. The number of observations (entities) in this sector were respectively 31 for 2015 and 24 for 2016.

In Merchandising sector, Model IV, we analyzed 101 entities for year 2015 and the results show a statistically significant 
model Wald $\chi^{2} \quad(\mathrm{DF}=5)=19.46, \quad(\mathrm{p}-$ value $<0.01$ ), Pseudo $R^{2}$ is 0.295 . The total percentage of correctly classifying all the entities both with high and low risk in the Merchandising sector is $84.2 \%$ (Table 5). The Total Debt ratio (p-value $<0.01)$ and the Revenues (p-value<0.05) are both statistically significant for this Model (Table 5). Other ratios, the NCA ratio, Inventory Ratio and the Net profit margin are all not statistically significant. In year 2016, Model
IV for the Merchandising Sector included 108 entities and was statistically significant $\chi^{2}(\mathrm{DF}=5)=14.588,(\mathrm{p}$-value $<0.05)$. The total percentage of correctly classifying all the entities both with high and low risk in this year was $85.2 \%$. The ratios that we find statistically significant for year 2016 are the NCA Ratio (p-value<0.05) and the Revenues (p-value $<0.1)($ table 5).

\begin{tabular}{|c|c|c|c|c|c|c|c|c|}
\hline & \multicolumn{4}{|l|}{2015} & \multicolumn{4}{|l|}{2016} \\
\hline & $\mathrm{B}$ & S.E. & Wald & $\operatorname{Exp}(\beta)$ & $\mathrm{B}$ & S.E. & Wald & $\operatorname{Exp}(\beta)$ \\
\hline Total Debt Ratio & $-\overline{3.199 * *}$ & 1.150 & 7.740 & .041 & .517 & .586 & .780 & 1.678 \\
\hline NCA Ratio & 1.332 & 1.391 & .917 & 3.787 & $-\overline{2.486 * *}$ & 1.256 & 3.917 & .083 \\
\hline Inventory Ratio & -.225 & 1.033 & .047 & .798 & -1.055 & 1.057 & .996 & .348 \\
\hline Net profit margin & -.879 & 1.941 & .205 & .415 & -5.406 & 4.635 & 1.361 & .004 \\
\hline Revenues & $.000 * *$ & .000 & 4.123 & 1.000 & $.000 *$ & .000 & 3.067 & 1.000 \\
\hline Constant & $2.976 * *$ & 1.042 & 8.155 & 19.607 & $2.112 * *$ & .881 & 5.741 & 8.263 \\
\hline
\end{tabular}

Table 5: Logistic Regression Analysis, Model IV, for data for sector 3, Merchandising in each of the two years. Source: Primary data of the study. $(* \mathrm{p}<0.1 * * \mathrm{p}<0.05 * * *<0.01)$

After running the regression separately for each sector, from the results of the individual models (Model II and Model IV, because Model III was not statistically significant) we observe that the dependent variables (financial ratios), behave differently in different sectors and in companies with different size (the Revenues is the control variable). In Construction and Manufacturing, inventory was a significant ratio which means that the higher the inventory levels of entities in this sector, the higher is the tax risk of that entity. Revenues and other variables are not significant for this specific sector, while keeping in mind that revenues were significant for the total set of firms (Model I). Of course, considering the limitation of database we are careful to not jump into conclusions, but overall, it seems that the amount of Inventory is an important risk indicator for construction and manufacturing companies.
In the Merchandising sector (Model IV), the total debt ratio, the NCA Ratio and the Revenues are statistically significant, so they are in total compatibility with the results from Model I. We conclude that for the Merchandising sector, specific risk indicators are high levels of total debt and high levels of investments in Fixed Assets.

\section{Main findings and conclusions}

The aim of this research is to empirically study the linkage between financial statement ratios and the level of magnitude of tax risk. For purposes of this study and based on literature, the level of tax audit risk is measured by the magnitude of the tax evasion detected in the companies audited in Albania during 2017. The independent variables of the study are a list of eighteen ratios and indexes, mainly from the reported financial statements and the filed tax return of the entities which were subject of a tax audit in 
2017. Out of a total of 1402 entities that were tax audited in 2017 we randomly selected 183 to include in our sample. We calculated eighteen financial ratios for each entity for two consecutive years, 2015 and 2016 and analyzed the respective Tax Audit Reports to calculate the magnitude of the tax evasion. Based on the latter we assigned the entities in the category they belong regarding the level of tax audit risk.

We used both univariate and multivariate techniques to analyze the dataset. In the univariate technique we coded each of the financial ratio with 0 if its calculated value was close or better than the optimal value and with 1 if its calculated value was worse than the optimal value. We did not include that specific variable in the univariate analysis if no optimal or threshold value could be identified for it. Consequently, we were left with 10 ratios only to continue the analysis.

The results of the univariate technique reveal that among the three liquidity ratios (current, acid test and liquid ratio) only the liquid ratio is statistically important. Entities with a high level of liquid ratio were found to have a low level of tax risk. Among the solvency ratios we found that only the total debt ratio was significant and disclosed important information on the tax risk. Entities with high debt ratio have a higher tax audit risk. In the profitability category we find only ROE to be an important ratio. As a next step we applied the univariate analysis separately for each sector, but the results were mixed, and no obvious trend could be identified.

Next, we applied the multivariate analysis to our sample, and we used the logistic regression to identify which specific ratio and index (independent variables) is linked to tax audit risk (the dependent variable). We did not rely on the optimal or standard values of the ratios, and therefore could include in our calculations all the eighteen financial ratios that we initially calculated and included in the dataset. We discarded from the model those variables which were highly correlated among them and, the outliers. We build four different models in the multivariate analysis.

Model I, regression for all the entities in the sample, despite their sector.

Model II, regression analysis for Construction and Manufacturing Sector.

Model III, regression analysis for Services and Transportation Sector.

Model IV, regression analysis for Merchandising Sector.

Results from Model I revealed it was statistically significant $\chi^{2} \quad(\mathrm{DF}=5)$ $=16.334, \quad(p-v a l u e<0.01)$ for $2015 \quad(p-$ value $<0.01$ ) for 2016. The percentage of correctly classifying all the entities both with high and low risk is $84.6 \%$ in 2015 and $85.6 \%$ in 2016 . Statistically significant ratios for both years and for all the companies are (1) Total debt ratio, (1) Total Revenues, (3) Non-current assets ratio and (4) Inventory Ratio. We notice, quite surprisingly that net profit margin is not statistically significant in Model I, which could be explained by high accounting cosmetics techniques that are usually applied to this ratio so that the company would not "get caught" by the tax auditors.

Model II for the Construction \& Manufacturing sector for year 2015 was statistically significant at $0.1 \mathrm{p}$-value $=0.073$. For 2015 the only statistically significant variable is the Inventory Ratio. Model II for year 2016 was not statistically significant. Model III, regression analysis for Services and Transportation Sector yielded not statistically significant results for both years (probably due to fewer entities in this sector). Model IV for the Merchandising sector for year 2015 was statistically significant $(p<0.01)$ and $(p<0.05)$ for year 2016. The statistically significant ratios in this model 
are the total debt ratio, the Revenues, and the Non-Current Assets Ratio.

Overall, based on results from both univariate and multivariate analysis we can conclude that the most common variables in these models that are linked to tax risk are the (1) liquid ratio, (2) ROE, (3) total debt ratio, (4) inventory ratio and (5) Non-Current assets ratio. Counter wise to the widely spread beliefs that profit margin ratios do contain information on tax risk, we found no relation between these margins and the tax evasion magnitude probably due to many ways (and potentially manipulative as well) that this ratio is calculated and the low quality of data where it is based upon.

The above traditional and wellknown financial ratios that can be easily calculated based on reported financial statements only, could indicate quite accurately the high risk of tax audits. Therefore, we suggest that these ratios could be included in the daily work procedures of the tax auditors, for example in the Internal Manuals or various trainings. These ratios could also serve as risk indicators or as red flags by other financial auditors, but still be used with caution due to specifics that each company demonstrates in practice regarding the way these ratios are calculated, especially in several sectors.

This research has several contributions in the field of financial ratios and tax audit because it helps to enrich the literature database with studies on a specific field. It also contributes by suggesting specific indicators that could be easily calculated based on reported published financial information and that could be helpful in daily procedures of auditors. Also, for the purpose of this research, the authors have compiled a new database with financial information and audit reports for many companies in Albania. Nevertheless, this research has its own restrictions in terms of limited timeframe, database, and application techniques. Other authors could use more recent information, extended in more countries than Albania only and experiment in applying innovative techniques that we mentioned during the literature review, such as Neural Networks, or Expert Systems.

\section{References:}

[1] Zhuo Zhang, Jia Wang, Financial Model based on Principle Component Analysis and Support Vector Machine, International Journal of Circuits, Systems and Signal Processing, pp. 183190, Volume 13, 2019.

[2] Valbona Cinaj, Manuela Mece, Artur Ribaj, Ilda Kadrimi, The Need for Improvement of External Audit Reports of Banks (The Case of Banks in Albania which Mainly belong to EU Banks), WSEAS Transactions on Environment and Development, ISSN / E-ISSN: 17905079 / 2224-3496, Volume 16, 2020, Art. \#55, pp. 539-547.

[3] Albrecht, S. and Romney, M. (1986) 'Redflagging management: a validation', Advances in Accounting, 3: 323-33.

[4] Arens, A. and Loebbecke, J. (1994) Auditing: An Integrated Approach, 6th ed. Englewood Cliffs, NJ: Prentice-Hall.

[5] Beasley, M. (1996) 'An empirical analysis of the relation between board of director composition and financial statement fraud', Accounting Review, 71(4): 44366.

[6] Bologna, G., Lindquist, R. and Wells, J. (1996) The Accountant's Handbook of Fraud and Commercial Crime. New York: John Wiley.

[7] Beaver W.H. (1966) 'Financial Ratios As Predictors of Failure', Journal of Accounting Research, Vol. 4, Empirical Research in Accounting: Selected Studies pp. 71-111

[8] Beneish M. (1999) The Detection of Earnings Manipulation, Financial Analysts Journal, 55:5, 24-36, DOI: 10.2469/faj.v55.n5.2296

[9] Bell, T., Szykowny, S. and Willingham, J. (1993) 'Assessing the likelihood of 
fraudulent financial reporting: a cascaded logic approach', Working Paper, KPMG Peat Marwick, Montvale, NJ.

[10] Green, B. (1991) 'Identifying management irregularities through preliminary analytical procedures', unpublished doctoral dissertation, Kent State University.

[11] Green, B. P. and Choi, J. H. (1997) 'Assessing the risk of management fraud through neural network technology', Auditing: A Journal of Practice and Theory, 16(1): 14-28.

[12] Davia, H., Coggins, P., Wideman, J. and Kastantin, J. (1992) Management Accountant's Guide to Fraud Discovery and Control. New York: John Wiley.

[13] Hoffman, V. B. (1997) 'Discussion of the effects of SAS No. 82 on auditors' attention to fraud risk-factors and audit planning decisions', Journal of Accounting Research, 35(5): 99-104.

[14] Hollman, V. P. and Patton, J. M. (1997) 'Accountability, the dilution effect and conservatism in auditors' fraud judgments', Journal of Accounting Research, 35(2): 227-37. International Auditing Practices Committee (IAPC) (2001) The Auditor's Responsibility to Detect Fraud and Error in Financial Statements. International Statement on Auditing (ISA) 240.

[15] Palmrose, Z. (1987) 'Litigation and independent auditors: the role of business failures and management fraud', Auditing: A Journal of Practice and Theory, 6(2): 90-102.

[16] Schilit, H. (1993) Financial Shenanigans: How to Detect Accounting Gimmicks and Fraud in Financial Reports. New York: McGraw-Hill.

[17] Stice, J. (1991) 'Using financial and market information to identify pre-engagement market factors associated with lawsuits against auditors', Accounting Review, 66(3): 516-33.

[18] Loebbecke, J., Eining, M. and Willingham, J. (1989) 'Auditor's experience with material irregularities: frequency, nature, and detectability', Auditing: A Journal of Practice and Theory, 9: 1-28.
[19] Zimbelman, M. F. (1997) 'The effects of SAS No. 82 on auditors' attention to fraud risk factors and audit planning decisions', Journal of Accounting Research, 35(5): 75-9.

[20] Niskanen J \& Keloharju M (2000) Earnings cosmetics in a tax-driven accounting environment: evidence from Finnish public firms, European Accounting Review, 9:3, 443-452, DOI: 10.1080/09638180020017159.

[21] Spathis CH. Doumpos M \& Zopounidis C (2002) Detecting falsified financial statements: a comparative study using multicriteria analysis and multivariate statistical techniques, European Accounting Review, 11:3, 509-535, DOI: $10.1080 / 0963818022000000966$

[22] J.D. McCalden (2003) A method and apparatus for selecting taxpayers to audit by a tax collecting entity. Patented method. US Patents.

[23] Bay S, Kumaraswamy K, Markus G., Kumar R, Steier D M (2006) 'Large Scale Detection of Irregularities in Accounting Data' Center for Advanced Research, PricewaterhouseCoopers LLP, Conference Paper, 2006.

[24] Kearns, Grover S.; Barker, Katherine J.; and Danese, Stephen P. (2011) "Developing a Forensic Continuous Audit Model,"Journal of Digital Forensics, Security and Law: Vol. 6: No. 2, Article 4.

DOI:https://doi.org/10.15394/jdfsl.2011. 1094.

[25] Gupta, M and Nagadevara, V. (2007). Audit Selection Strategy for Improving Tax Compliance - Application of Data Mining Techniques. Downloaded from: https://www.researchgate.net/publicatio n/254667082_Audit_Selection_Strategy _for_Improving_Tax_Compliance__Application_of_Data_Mining_Techniq ues.

[26] Kallio M, Back B (2011) 'The SelfOrganizing Map in Selecting Companies for Tax Audit' chapter from book IS Success Evaluation: Theory and Practice (pp.347-358), downloaded by https://www.researchgate.net/publicatio 
n/227191297_The_Self-

Organizing_Map_in_Selecting_Compan ies_for_Tax_Audit.

[27] Watrin C, Struffert R, and Ullmann R (2008), 'Benford's Law: an instrument for selecting tax audit targets?' Review of Managerial Science 2: 219. https://doi.org/10.1007/s11846-0080019-9.

[28] Demir B and Javorcik B (2018) Using Benford's Law to detect tax fraud in international trade, Working Paper dowanladed by https://voxeu.org/article/using-benfords-law-detect-tax-fraud-internationaltrade

[29] Wells, J. 2001. "Irrational Ratios.” Journal of Accountancy (August): 80-83.

[30] Grove H. Basilico E (2008) Fraudulent Financial Reporting Detection: Key Ratios Plus Corporate Governance Factors, International Studies of Management \& Organization, 38:3, 1042, DOI: 10.2753/IMO00208825380301.

[31] Marghescu R, Dorina \& Tähtinen, Minna \& Back, Barbro. (2010). Using Financial Ratios to Select Companies for Tax Auditing: A Preliminary Study. Communications in Computer and Information Science. 112. 10.1007/9783-642-16324-1_45. Downloaded by https://www.researchgate.net/publicatio n/49288086_Using_Financial_Ratios_to _Select_Companies_for_Tax_Auditing_ A_Preliminary_Study.

[32] Neves Elisabete \& Dias, António \& Pinto, Carlos \& Batista, João. (2015). Signaling Tax Evasion by using Financial Ratios and Cluster Analysis. Signaling Tax Evasion by using Financial Ratios and Cluster Analysis. Working papers. Downloaded by https://www.researchgate.net/publicatio n/309187751_Signaling_Tax_Evasion_
by_using_Financial_Ratios_and_Cluster _Analysis.

[33] Shuli I. Earnings management and the quality of the financial reporting, Perspectives of Innovations, Economics and Business, Volume 8, Issue 2, 2011.

[34] Llukani, T. (2013). Earnings management and firm size: An empirical analyze in Albanian market. European Scientific Journal, 9(16), 135-143.

[35] Persons, O. (1995) 'Using financial statement data to identify factors associated with fraudulent financing reporting', Journal of Applied Business Research, 11(3): 38-46.

[36] Wright, A. and Ashton, R. (1989) 'Identifying audit adjustments with attention-direction procedures', Accounting Review, 64(4): 79-83.

[37] Feroz, E., Park, K. and Pastens, V. (1991) 'The financial and market effects of the SEC's accounting and auditing enforcement's releases', Journal of Accounting Research, 29: 107-42.

[38] Fanning, K. and Cogger, K. (1998) 'Neural detection of management fraud using published financial data', International Journal of Intelligent Systems in Accounting, Finance and Management, 7(1): 21-41.

[39] Daroca, F. and Holder, W. (1985) 'The use of analytical procedures in renew and audit engagements', Auditing: A Journal of Practice and Theory, 4: 80-92.

[40] Summers, S. L. and Sweeney, J. T. (1998) 'Fraudulently misstated financial statements and insider trading: an empirical analysis', Accounting Review, 73(1): 131-46.

[41] Chow, C. and Rice, S. (1982) 'Qualified audit opinions and share prices - an investigation', Auditing: A Journal of Practice and Theory, 1: 35-53. 


\section{Contribution of individual authors to the} creation of this scientific article

- Rezarta Perri Shkurti conceptualized the idea of the research and was responsible for all the

- stages of research, analysis, main findings, and of finally writing this paper.

- Elena Myftaraj Tomori was responsible for the Statistical Analysis and giving recommendations for the Methodology and Analysis.

- Elsia Gjika was responsible for gathering the dataset and giving professional opinion as to the practical implications of the findings of the study.

\section{Creative Commons Attribution License 4.0 (Attribution 4.0 International, CC BY 4.0)}

This article is published under the terms of the Creative Commons Attribution License 4.0

https://creativecommons.org/licenses/by/4.0/deed.en US 